\title{
Принципи терапії когнітивних порушень при депресивних розладах
}

Мета - розробити та оцінити ефективність комплексної програми терапії та реабілітації (КПТР) пацієнтів з когнітивними порушеннями (КП) при депресивних розладах (ДР). Запропонована КПТР пацієнтів з КП при ДР реалізовувалася у чотири етапи: діагностичний, терапевтичний, реабілітаційний та профілактичний. Діагностичний етап включав клініко-психопатологічну оцінку наявних розладів когнітивної сфери, аналіз анамнестичних даних, клінічної симптоматики, динаміки та прогнозузахворювання, взаємозв'язку клінічних та соціально-психологічних факторів. Терапевтичний етап включав комплекс заходів фармакотерапії та психотерапії, спрямованих на корекцію КП, купірування ДР, нормалізацію психоемоційного стану, соціальну адаптацію та реадаптацію пацієнта. Реабілітаційний етап включав комплекс заходів фармако- та психотерапії, спрямованих на відновлення когнітивних функцій, укріплення ефекту від антидепресивної терапії, відновлення соціального функціонування пацієнта. Профілактичний етап призначений для підтримання нормального психоемоційного стану, ефективного спротиву стресу, запобіганню рецидивуванню ДР. В апробації розробленої КПТР взяли участь 97 пацієнтів із КП при ДР, що становили основну групу і пройшли курс КПТР. Контрольна група складалася із 93 хворих з КП при ДР, які пройшли курс терапії за традиційною схемою. Доведена ефективність запропонованої КПТР пацієнтів із КП при ДР, що полягала в більш вираженій редукції клінічних проявів депресії, поліпшенні когнітивних функцій, зниженні неадаптивних та підвищенні адаптивних стратегій когнітивного регулювання емоцій, покращенні соціального функціонування в основних сферах життедіяльності.

Ключові слова: когнітивні порушення, депресивні розлади, терапія, реабілітація, соціальне функціонування.

\section{Вступ}

Актуальність проблеми депресивних розладів (ДР) визначається їх значною поширеністю у загальній популяції, тенденцією до затяжного і хронічного перебігу і високим суїцидальним ризиком. Депресія - один із найпоширеніших психічних розладів (Азимова Ю.Э., 2017; Екушева Е.В., 2018). Згідно з даними епідеміологічних досліджень, ризик розвитку депресії протягом життя становить до $10 \%$ у чоловіків і до $20 \%$ - у жінок. Частота ДР у загальномедичній практиці варіює в межах 24-64\% (Crocker L.D. et al., 2013; Rock P.L et al., 2014; Азимова Ю.Э., 2017; Марута Н.О. та співавт., 2017). У зв'язку з високою поширеністю і негативним впливом на працездатність депресія належить до одних із найбільш затратних для суспільства захворювань (Mclntyre R.S. et al., 2013; Абдурахманова Р.Ф. и соавт., 2015; Захаров В.В., Вахнина Н.В., 2015). Так, за даними фармакоекономічних досліджень, у США щорічні збитки від депресії оцінюють у приблизно 83 млрд дол., а в країнах Європейського Союзу - у 75 млрд євро (Martin J.L. et al., 2014).

Когнітивний компонент робить істотний внесок у загальну картину депресії, що знаходить відображення в описі клінічних симптомів і діагностичних критеріїв депресії (Disner S.G. et al., 2011; Lee R.S et al., 2012; Гимоян Л.Г., Силванян Г.Г., 2013). В останні роки когнітивному аспекту депресії приділяють особливу увагу (Добрянская М., 2010; Roiser J.P., Sahakian B.J., 2013; Захаров В.В., Вахнина Н.В., 2015). Показано, що корекція когнітивних розладів має першорядне значення для нормалізації повсякденного функціонування пацієнтів при досягненні ремісії, зокрема для відновлення порушеної працездатності (Disner S.G. et al., 2011; Leiser S.C. et al., 2012; Meusel L.A. et al., 2013; Ilamakar K.R., 2014). Досягнення задовільного рівня повсякденного функціонування неможливе без відновлення нормального рівня розумової працездатності пацієнта, тобто без додаткового впливу на когнітивну складову (Ильницкая Т., 2016; Fernández-Blázquez M.A. et al., 2016; Мищенко Т.С., 2017). За даними Всесвітньої організації охорони здоров'я, у понад 20 млн людей у світі наявні когнітивні порушення (КП), і цей показник неухильно зростає (Мищенко Т.С., 2017). Проблема збереження і відновлення когнітивних функцій стає міждисциплінарною та однією з глобальних у сучасній медицині (Добрянская М., 2010; Ушкалова Е.А., Ушкалова А.В., 2014; Захаров В.В., Вахнина Н.В., 2015).
При виборі тактики корекції КП особливе значення має розуміння патогенетичних механізмів їх розвитку, які чималою мірою визначаються наявністю тих чи інших факторів ризику (Milders M. et al., 2010; Абдурахманова Р.Ф. и соавт., 2015; Burmester В. et al., 2016; Азимова Ю.Э., 2017). 3 урахуванням патогенетичних уявлень профілактичні заходи повинні бути спрямовані на корекцію відомих факторів ризику КП (Гимоян Л.Г., Силванян Г.Г., 2013; Захаров В.В., Вахнина Н.В., 2015; Екушева Е.В., 2018). На сьогодні відсутня єдина стандартизована терапія когнітивних дисфункцій при ДР (Захаров В.В., Вахнина Н.В., 2015). Вищезазначене свідчить про високу актуальність проблеми КП при депресивних станах, її високу практичну і теоретичну значущість.

Мета дослідження - створення, апробація та оцінка ефективності комплексної терапії пацієнтів із КП при ДР.

Комплексна терапія пацієнтів із КП при ДР має відповідати основним загальним принципам, які полягають у комплексності підходу, що передбачає:

- єдність біологічних, психотерапевтичних та соціально-психологічних впливів у лікувально-реабілітаційному процесі;

- дотримання етапності та послідовності терапевтичних заходів;

- індивідуально орієнтований та диференційований характер терапії залежно від особливостей клінічних проявів ДР і пов'язаних з ними КП;

- оптимальну тривалість терапії;

- надання психопрофілактичних рекомендацій.

Для досягнення високого рівня ефективності у разі проведення терапії КП при ДР слід дотримуватися певних умов:

- формування терапевтичного альянсу між лікарем і пацієнтом, а також (за можливістю) - з родиною хворого;

- забезпечення пацієнта та членів його родини інформацією про КП та ДР у доступній для них формі;

- залучення пацієнта до обговорення терапевтичної тактики, що дозволяє підвищити рівень дотримання режиму лікування i, тим самим, сприяти підвищенню комплаєнсу та ефективності терапії.

Метою комплексної програми терапії та реабілітації (КПТР) пацієнтів із КП при ДР є:

1. Зменшення вираженості КП.

2. Усунення поточних клінічних проявів депресії.

3. Зміна патологічних когнітивних патернів, асоційованих із наявністю ДР. 
4. Максимальне відновлення працездатності та соціального функціонування пацієнтів.

5. Проведення профілактики рецидивів ДР.

6. Запобігання хроніфікації КП.

7. Профілактика суїцидальної поведінки.

8. Забезпечення ранньої реінтеграції та соціальної адаптації пацієнтів.

9. Поліпшення якості життя та соціального функціонування пацієнтів.

Рекомендована комплексна терапія і реабілітація пацієнтів із КП при ДР реалізується в чотири етапи: діагностичний, терапевтичний, реабілітаційний та профілактичний (рисунок).

\section{I етап - діагностичний}

Включає клініко-психопатологічну оцінку наявних у хворого розладів когнітивної сфери, аналіз анамнестичних даних, клінічної симптоматики, динаміки та прогнозу захворювання, взаємозв'язку клінічних та соціально-психологічних факторів. На цьому етапі здійснюють оцінку психічного статусу хворого, а саме: верифікацію діагнозу ДР, його класифікацію; визначення етіопатогенетичних механізмів розвитку ДР у хворого, особливостей клініки, динаміки та прогнозу; детальний аналіз особливостей КП з використанням клініко-психопатологічного, психодіагностичного та психометричного методів. На підставі даних обстеження розробляють план заходів з метою корекції КП, усунення проявів ДР, адаптації та реадаптації пацієнта.

\section{II етап - терапевтичний}

Включає комплекс заходів фармакотерапії та психотерапії, спрямованих на корекцію КП, купірування ДР, нормалізацію пси хоемоційного стану, соціальну адаптацію та реадаптацію пацієнта. Фармакотерапія на цьому етапі спрямована на корекцію КП, редукцію депресивної симптоматики. Психотерапевтичні та реабілітаційні втручання передбачають поєднання психоосвітніх заходів, когнітивно-поведінкової психотерапії, тренінгу когнітивних функцій. Тривалість етапу - 1-2 міс.

\section{III етап - реабілітаційний}

Включає комплекс заходів фармакотерапії та психотерапії, спрямованих на відновлення когнітивних функцій, укріплення ефекту від антидепресивної терапії, відновлення соціального функціонування пацієнта. Реабілітаційний етап може розпочинатися вже під час стаціонарного лікування (за умови редукції депресивної симптоматики) і тривати 3-12 міс після виписки зі стаціонару. Основним завданням цього етапу є формування стійкого адекватного емоційно-поведінкового патерну, відновлення когнітивних функцій, максимальна адаптація та реадаптація хворого, недопущення рецидиву ДР. Фармакотерапія на реабілітаційному етапі аналогічна тій, що застосовували на терапевтичному етапі, з відповідною корекцією дозування препаратів залежно від актуального стану пацієнта.

На реабілітаційному етапі продовжують диференційовану психотерапевтичну роботу з пацієнтами, що полягає у поєднанні когнітивно-поведінкової психотерапії, тренінгу ефективних копінгстратегій та комунікативному тренінгу. На цьому етапі також особливого значення набувають заходи з соціальної реабілітації та реадаптації пацієнта. Соціальна реабілітація передбачає заходи з соціально-середовищної та соціально-побутової підтримки з метою відновлення втрачених та формування нових соціальних зв'язків і відносин. Пацієнтів стимулюють до різних видів соціальної діяльності (робота, навчання, творчість, оздоровлення, суспільна діяльність тощо), відновлення професійного статусу й ефективну професійну реалізацію.

\section{IV етап - профілактичний}

Призначений для підтримання нормального психоемоційного стану, ефективній протидії стресу, запобіганню рецидиву ДР та орієнтований на тривалий час (до двох років). Фармакотерапія на цьому етапі включає лікування основного захворювання при ДР та сезонну профілактику депресії ендогенного характеру. Психотерапія представлена переважно техніками саморегуляції, що спрямовані на самоконтроль емоційного стану і запобігання рецидиву депресії.

Визначені диференційовані діагностичні маркери-мішені КП при ДР. Встановлено, що диференційно-діагностичні критерії включають когнітивні та клініко-психопатологічні маркери-мішені.

Когнітивні маркери-мішені при рекурентному ДР: зниження інтересу, труднощі у прийнятті рішень та абстрагуванні, ригідність мислення, іпохондричні ідеї, нав'язливі думки, зниження рівня короткострокової пам'яті, помірні порушення відстроченого відтворення і вербальної продуктивності, помірні та виражені порушення зорово-моторної координації, виконавчих функцій та лексичної системи, знижений і низький рівень концентрації, переключення уваги та зміна працездатності, знижений рівень ефективності роботи, середній рівень стійкості уваги, підвищена та низька вибірковість уваги на нейтральні стимули, висока вибірковість уваги на негативні стимули, знижена і низька вибірковість уваги на позитивні стимули, когнітивні стратегії регулювання емоцій («розгляд ситуації у перспективі», «позитивне перефокусування»), слабкі порушення у сфері суспільно корисної діяльності, самообслуговуванні та агресивних патернів поведінки й помірні порушення особистісної та соціальної взаємодії.

Клініко-психопатологічні маркери-мішені при рекурентному ДР: підгострий початок депресії, тривалість депресивного епізо-

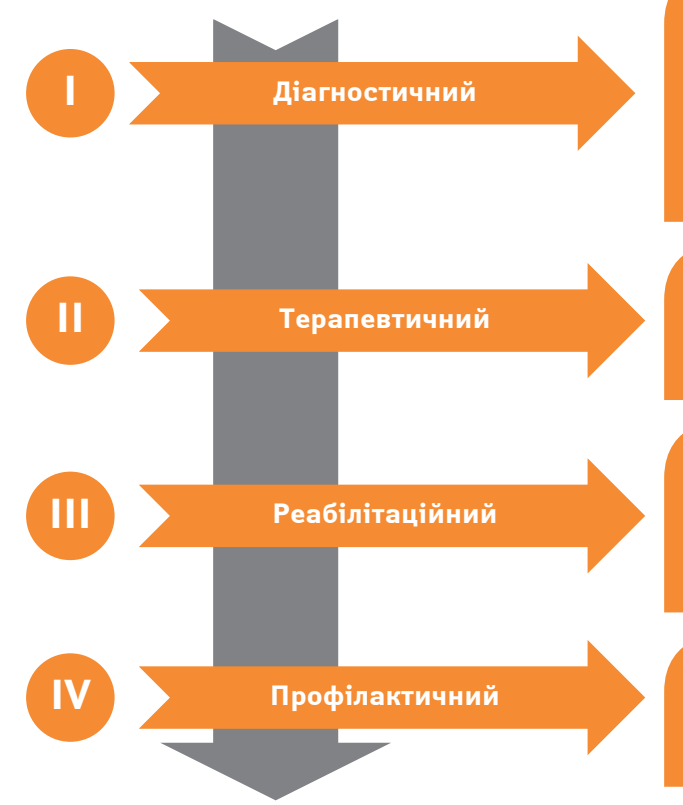

Оцінка психічного статусу пацієнта (верифікація діагнозу депресивного розладу, його класифікація; аналіз суїцидального ризику.

Визначення етіопатогенетичних механізмів розвитку депресивного розладу. особливостей клініки, динаміки та прогнозу).

Клініко-психопатологічна та психодіагностична оцінка розладів когнітивної сфери.

Визначення мішеней фармако- та психотерапії

Фармакотерапія (антидепресанти, нейролептики, нормотиміки.

ноотропи, антиоксиданти).

Психотерапія (когнітивно-поведінкова психотерапія, психоосвіта, тренінг когнітивних функцій)

Фармакотерапія (антидепресанти, нейролептики, нормотимики, ноотропи, антиоксиданти).

Психотерапія (когнітивно-поведінкова психотерапія, тренінг ефективних копінг-стратегій, комунікативний тренінг).

Заходи з соціальної адаптації та реадаптації

Фармакотерапія, спрямована на основне захворювання

та сезонні загострення.

Аутосугестивна психотерапія і саморегуляція.

Професійна та соціальна адаптація

Рисунок. Чотири етапи комплексної терапії у пацієнтів із КП при ДР 
ду до 3 та 6 міс, наявність 1-2 та 3-5 епізодів в анамнезі, тривалість ремісії 6-12 та 12-24 міс, вираженість астено-анергетичного, апатико-адинамічного і тривожного симптомокомплексів, наявність депресивного настрою, суб'єктивних та об'єктивних ознак пригніченості, почуття провини, соматичної тривоги, загальмованості, серцево-судинних та гастроінтестинальних симптомів, порушень сну, зниження апетиту, зменшення маси тіла, гіпестезії, анестезії, емоційної лабільності, загальмованості рухів, гіпомімії та відчуття зневіри.

Когнітивні маркери-мішені при біполярному афективному розладі: виснаженість психічної діяльності, параноїдні розлади, зниження абстрактного мислення, апатія, підвищена чутливість до критики, труднощі у прийнятті рішень, ідеї малоцінності, знижений рівень відстроченого відтворення та короткострокової пам'яті, помірні та виражені порушення зорово-моторної координації, виконавчих функцій, лексичної системи, вербальної продуктивності, знижений та низький рівень концентрації уваги і працездатності, середній та підвищений рівні переключення уваги, низький рівень ефективності роботи і психічної стійкості, знижений рівень стійкості уваги, середня та знижена вибірковість уваги на нейтральні стимули, середня вибірковість уваги на негативні та позитивні стимули, використання когнітивних стратегій регулювання емоцій: “самозвинувачення», «катастрофізація», «звинувачення інших», «румінації» та «ухвалення», значні порушення у сфері суспільно корисної діяльності, особистісної та соціальної взаємодії, помірні, значні та виражені порушення в самообслуговуванні, помірні та значні порушення у сфері агресивних патернів поведінки.

Клініко-психопатологічні маркери-мішені при біполярному афективному розладі: гострий початок депресії, тривалість депресивного епізоду до 6 міс та 1 року, наявність $>5$ епізодів в анамнезі, тривалість ремісії 12-24 міс, переважання астеноанергетичного, апатико-адинамічного і тужливого симптомокомплексів, наявність загальмованості, суб'єктивних ознак пригніченості, апатії, збудженості, деперсоналізації/дереалізації, емоційної холодності, емоційної амбівалентності, дисфорії, порушень сну, гіпотимії, незадоволеності, відчуття туги і досади, загальмованості рухів, м'язової адинамії, запору, сексуальних порушень, гіпестезії, сенестопатії та розладів схеми тіла.

Когнітивні маркери-мішені при пролонгованій депресивній реакції: нав'язливі та суїцидальні думки, іпохондричні ідеї, підвищена чутливість до критики, високий рівень відстроченого відтворення, слабкі порушення зорово-моторної координації, виконавчих функцій, лексичної системи та вербальної продуктивності, середній рівень концентрації уваги, психічної стійкості і працездатності, знижений та низький рівні переключення уваги, середній та підвищений рівень ефективності роботи та стійкості уваги, середня та знижена вибірковість уваги на нейтральні стимули, знижена та низька вибірковість уваги на негативні стимули, підвищена вибірковість уваги на позитивні стимули, використання когнітивних стратегій регулювання емоцій: «румінації», «звинувачення інших», «катастрофізація», «фокусування на плануванні», «позитивне перефокусування» та «позитивна переоцінка», слабкі порушення у сфері суспільно корисної діяльності та помірні порушення у сфері агресивних патернів поведінки.

Клініко-психопатологічні маркери-мішені при пролонгованій депресивній реакції: затяжний початок депресії, тривалість депресивного епізоду до $1 ; 1,5$ та 2 років, наявність $1-2$ епізодів в анамнезі, тривалість ремісії $>24$ міс, переважання тривожного симптомокомплексу, внутрішне напруження, психічна та соматична тривога, почуття провини, сенситивність, емоційна лабільність, відчуття відчаю, побоювань, злості, неприязні, сорому, наявність рухового занепокоєння, вегетовісцеральних кризів, головного болю, сексуальних порушень, порушень з боку шлунково-кишкового тракту та гіперстезії.

Структура заходів із комплексного лікування ДР включала реалізацію плану фармакотерапевтичних заходів, розробленого на підставі даних, одержаних на діагностичному етапі. Медикаментозну терапію проводили з урахуванням таких загальних принципів:

- адекватний вибір препарату з урахуванням особливостей КП та клінічних проявів ДР;
- призначення препарату в ефективних терапевтичних дозах, забезпечення оптимального балансу між лікувальним та побічним ефектами в межах терапевтичного вікна;

- достатня тривалість терапії, що має становити щонайменше 6 міс;

- поступове зниження дози препарату під контролем вираженості депресивних проявів;

- постійний контроль ефективності фармакотерапії;

- за наявності показань призначення інших препаратів психотропної дії (нейролептиків, транквілізаторів, адаптогенів, препаратів для активації мозкового кровообігу тощо);

- індивідуальна корекція схем лікування у кожного пацієнта залежно від особливостей клініки та динаміки розладу.

Особливості терапевтичної тактики пацієнтів із КП при ДР визначались особливостями перебігу депресії (провідного симптомокомплексу) та наявними КП.

Фармакотерапія КП при рекурентному ДР включала застосування антидепресантів групи інгібіторів зворотного захвату серотоніну - норадреналіну (венлафаксин у дозі 75-150 мг/добу) та модуляторів серотоніну (міртазопін - 15-30 мг/добу) з поєднаним застосуванням нейролептиків (кветіапін - 100-300 мг/добу) та антиоксидантів (вітамін Е).

Фармакотерапія КП при біполярному афективному розладі включала застосування антидепресантів групи модуляторів серотоніну (тразодон у дозі 150-300 мг/добу) з поєднаним призначенням нейролептиків (кветіапін - 300 мг/добу), нормотиміків (ламотриджин - 50-200 мг/добу, літій - 400-600 мг/добу) та додатковим застосуванням антиоксидантів (вітамін Е).

Фармакотерапія КП при пролонгованій депресивній реакції включала застосування антидепресантів групи модуляторів серотоніну (тразодон у дозі 150 мг/добу) та мелатонінергічних антидепресантів (агомелатин - 25-50 мг/добу) з поєднаним призначенням нормотиміків (карбамазепін - 200-400 мг/добу) та ноотропних препаратів (фенібут - 500 мг/добу).

\section{Об'єкт і методи дослідження}

Апробацію КПТР пацієнтів із КП при ДР проводили на базі КНП «Херсонський обласний заклад з надання психіатричної допомоги». В апробації розробленої КПТР взяли участь 190 пацієнтів із КП при ДР: 97 осіб, які пройшли курс КПТР за розробленою програмою (основна група) та 93, які пройшли курс терапії за традиційною схемою (контрольна група). При оцінці ефективності КПТР використані: клініко-психопатологічний метод, психометричний метод (шкала депресії MADRS (Montgomery-Asberg Depression Rating Scale), Монреальська шкала оцінки когнітивних функцій (Montreal Cognitive Assessment), модифікована Адденбрукська шкала оцінки когнітивних здібностей (Addenbrooke's Cognitive Examination - Revised), психодіагностичний метод (опитувальник когнітивної регуляції емоцій, шкала особистісного та соціального функціонування (Personal and Social Performance Scale) та статистичний метод.

Порівняльну оцінку ефективності розробленої комплексної програми терапії та реабілітації пацієнтів із КП при ДР відносно традиційної проводили шляхом зіставлення даних клініко-психологічного та психометричного дослідження.

Критерії ефективності КПТР:

- клінічна динаміка ДР;

- ступінь поліпшення/погіршення когнітивних функцій (погіршення, відсутність ефекту, мінімальне поліпшення, помірне поліпшення):

- особливості когнітивного регулювання емоцій;

- рівень соціального функціонування;

- ступінь відновлення основних функцій життєдіяльності.

\section{Результати та їх обговорення}

Виявлено (таблиця) суттєві зміни в результаті проведення лікування КП при ДР в обох групах. Клінічна динаміка психічного стану хворих основної групи після проведення КПТР визначалася суттєвим зменшенням вираженості об'єктивних та суб'єктивних ознак пригніченості, зниженням внутрішнього напруження, покращенням сну та концентрації уваги, редукцією апатії, песимістичних та суїцидальних думок. У пацієнтів контрольної групи визначали зменшення вираженості об'єктивних ознак пригніченості і внутрішнього напруження, покращення апетиту, редукцію 
апатії та суїцидальних думок. Оцінка динаміки когнітивних функцій продемонструвала, що у більшості $(50,52 \%)$ пацієнтів основної групи після лікування за розробленою КПТР визначали помірне поліпшення когнітивних функцій (ДК=3,10, Ml=0,40), у більшості $(50,54 \%)$ пацієнтів контрольної групи - мінімальне покращення когнітивних функцій (ДК=1,11, Ml=0,06) та у $18,28 \%$ - відсутність ефекту (ДК=3,46, MI=0,17).

Таблиця. Вірогідні зміни за результатами лікування КП при ДР

\begin{tabular}{|c|c|c|c|}
\hline $\begin{array}{l}\text { Критерій } \\
\text { оцінки }\end{array}$ & Показник & $\begin{array}{c}\text { Основ- } \\
\text { на } \\
\text { група }\end{array}$ & $\begin{array}{c}\text { Контро- } \\
\text { льна } \\
\text { група }\end{array}$ \\
\hline & & & \\
\hline \multirow[t]{9}{*}{$\begin{array}{l}\text { Клінічна } \\
\text { динаміка ДР }\end{array}$} & $\begin{array}{l}\text { Зменшення вираженості об'єктивних ознак } \\
\text { пригніченості }\end{array}$ & 0,0237 & 0,0413 \\
\hline & $\begin{array}{l}\text { Зменшення вираженості суб'єктивних ознак } \\
\text { пригніченості }\end{array}$ & 0,0163 & \\
\hline & Зниження внутрішнього напруження & 0,0012 & 0,0258 \\
\hline & Покращення сну & 0,0381 & \\
\hline & Покращення апетиту & & 0,0143 \\
\hline & Покращення концентрації уваги & 0,0025 & \\
\hline & Редукція апатії & 0,0001 & 0,0253 \\
\hline & Редукція песимістичних думок & 0,0015 & \\
\hline & Редукція суїцидальних думок & 0,0256 & 0,0162 \\
\hline \multirow{3}{*}{$\begin{array}{l}\text { Динаміка } \\
\text { когнітивних } \\
\text { функцій }\end{array}$} & Помірне поліпшення когнітивних функцій & 0,0001 & \\
\hline & Мінімальне поліпшення когнітивних функцій & & 0,0339 \\
\hline & Відсутність ефекту & & 0,0216 \\
\hline \multirow{9}{*}{$\begin{array}{l}\text { Динаміка } \\
\text { особливостей } \\
\text { когнітивного } \\
\text { регулювання } \\
\text { емоцій }\end{array}$} & Зниження самозвинувачення & 0,0001 & 0,0361 \\
\hline & Зниження румінацій & 0,0001 & 0,0408 \\
\hline & Зниження катастрофізації & 0,0157 & 0,0287 \\
\hline & Зниження звинувачення інших & 0,0255 & \\
\hline & Актуалізація «ухвалення» & 0,0127 & \\
\hline & Актуалізація «позитивного перефокусування» & 0,0012 & \\
\hline & Актуалізація «фокусування на плануванні» & 0,0134 & \\
\hline & Актуалізація «позитивної переоцінки» & 0,0328 & \\
\hline & Актуалізація «розгляду в перспективі» & 0,0254 & \\
\hline \multirow{3}{*}{$\begin{array}{l}\text { Динаміка } \\
\text { соціального } \\
\text { функціонуван- } \\
\text { ня }\end{array}$} & $\begin{array}{l}\text { Зменшення порушень у сфері особових } \\
\text { та соціальних взаємовідносин }\end{array}$ & 0,0136 & 0,0362 \\
\hline & Зменшення порушень у самообслуговуванні & 0,0409 & 0,0453 \\
\hline & Зниження агресивних патернів поведінки & 0,0251 & \\
\hline
\end{tabular}

Аналіз динаміки особливостей когнітивного регулювання емоцій продемонстрував, що у пацієнтів основної групи після лікування відзначали виражену позитивну динаміку, що виражалась у зниженні неадаптивних когнітивних стратегій регулювання емоцій (самозвинувачення, румінацій та катастрофізації) та у суттєвому підвищенні адаптивних стратегій («ухвалення», «позитивне перефокусування», «фокусування на плануванні», «позитивна переоцінка» та «розгляд у перспективі»). У пацієнтів контрольної групи зафіксована позитивна динаміка, що полягала у зменшенні вираженості неадаптивних когнітивних стратегій регулювання емоцій («самозвинувачення», «румінації» та «катастрофізація»), однак не встановлено суттєвих відмінностей щодо збільшення вираженості адаптивних стратегій регулювання емоцій.

Динаміка соціального функціонування у пацієнтів основної групи визначалася суттєвим зменшенням порушень у сферах суспільно корисної діяльності, особових та соціальних взаємовідносин і самообслуговування та зниженням агресивних патернів поведінки, а у пацієнтів контрольної групи визначалася позитивна динаміка соціального функціонування пацієнтів у сфері самообслуговування, а також особових та соціальних взаємовідносин.

\section{Висновки}

Доведена ефективність запропонованої схеми КПТР пацієнтів із депресивними порушеннями, що полягала у більш вираженій редукції клінічних проявів ДР, поліпшенні когнітивних функцій, зниженні неадаптивних та підвищенні адаптивних стратегій когнітивного регулювання емоцій, покращенні соціального функціонування в основних сферах життєдіяльності.

\section{Перспективи подальших досліджень}

Розроблена комплексна програма терапії та реабілітації пацієнтів із КП при ДР показала свою ефективність та може бути використана у психокорекційних заходах, спрямованих на лікування цієї групи пацієнтів.

\section{Список використаної літератури}

Абдурахманова Р.Ф., Иззатов Х.Н., Хадибаева Г.Р. и др. (2015) Депрессии в неврологической практике: применение антидепрессантов (http:// www.vestnik-ipovszrt.tj/?p=2254).

Азимова Ю.Э. (2017) Депрессия и когнитивные нарушения: опыт использования вортиоксетина в неврологической практике. Мед. совет, 11: 36-39.

Гимоян Л.Г., Силванян Г.Г. (2013) Нарушение когнитивных функций: актуальность проблемы, факторы риска, возможности профилактики и лечения (https://cyberleninka.ru/article/n/narushenie-kognitivnyh-funktsiy-aktualnostproblemy-faktory-riska-vozmozhnosti-profilaktiki-i-lecheniya).

Добрянская М. (2010) Современные аспекты лечения когнитивной дисфункции. Hейрonews, 7(26): 46-52.

Екушева Е.В. (2018) Когнитивные нарушения - актуальная междисциплинарная проблема. РМЖ, 12(I): 32-37.

Захаров В.В., Вахнина Н.В. (2015) Когнитивные нарушения при депрессии. Эффект. фармакотер., 1: 18-26.

Ильницкая Т. (2016) Когнитивные нарушения у пациентов с психической и неврологической патологией (https://neuronews.com.ua/uploads/ issues/2016/8(82)/nn16-8 14-16 ea8724143e5f7777b4bfad8994b5708a.pdf).

Марута Н.О., Панько Т.В., Федченко В.Ю. та ін. (2017) Діагностичні критерії депресивних розладів на етапах надання медичної допомоги. Укр. вісн. психоневрол., Т. 25, 1(90): 135.

Мищенко Т.С. (2017) Когнитивные нарушения в практике семейного врача (актуальность проблемы, факторы риска, патогенез, возможности лечения и профилактики). Семейная медицина, 1(69): 21-24.

Ушкалова Е.А., Ушкалова А.В. (2014) Фармакотерапия когнитивных нарушений различного генеза: современное состояние и перспективные направления. РМЖ, 22: 1613.

Burmester B., Leathem J., Merrick P. (2016) Subjective cognitive complaints and objective cognitive function in aging: a systematic review and metaanalysis of cross-sectional finding. Neuropsychology, 26(4): 376-393.

Crocker L.D., Heller W., Warren S.L. et al. (2013) Relationships among cognition, emotion, and motivation: implications for intervention and neuroplasticity in psychopathology. Front. Hum. Neurosci., 7: 261.

Disner S.G., Beevers C.G., Haigh E.A., Beck A.T. (2011) Neural mechanisms of the cognitive model of depression. Nat. Rev. Neurosci., 12(8): 467-477.

Fernández-Blázquez M.A., Avila-Villanueva M., Maestu F. et al. (2016) Specific features of subjective cognitive decline predict faster conversion to mild cognitive impairment. J. Alzheimers Dis., 52(1): 272-281.

Ilamakar K.R. (2014) Psychomotor retardation, attention deficit and executive dysfunctional in young non-hospitalised unmedicated non-psychotic unipolar depression patients. J. Clin. Diagn. Res., 8(2): 124-126.

Lee R.S., Hermens D.F., Porter M.A., Redoblado-Hodge M.A. (2012) A meta-analysis of cognitive deficits in first-episode Major Depressive Disorder. J. Affect. Disord., 140(2): 113-124.

Leiser S.C., Pehrson A.L., Robichaud P.J. et al. (2012) Preclinical studies of the multimodal antidepressant vortioxetine support a potential for improvement of cognitive functions. Eur. Neuropsychopharmacol., 38: 164-165.

Martin J.L., McLean G., Park J. et al. (2014) Impact of socioeconomic deprivation on rate and cause of death in 159 severe mental illness. BMC Psychiatr., 14: 261. DOI: 10.1186/s12888-014-0261-4.

McIntyre R.S., Cha D.S., Soczynska J.K. et al. (2013) Cognitive deficits and functional outcomes in major depressive disorder: determinants, substrates, and treatment interventions. Depress. Anxiety, 30(6): 515-527.

Meusel L.A., Hall G.B., Fougere P. et al. (2013) Neural correlates of cognitive remediation in patients with mood disorders. Psychiatry Res., 214(2): 142-152.

Milders M., Bell S., Platt J. et al. (2010) Stable expression recognition abnormalities in unipolar depression. Psychiatry Res., 179(1): 38-42.

Rock P.L., Roiser J.P., Riedel W.J., Blackwell A.D. (2014) Cognitive impairment in depression: a systematic review and metaanalysis. Psychol. Med., 44(10): 2029-2040.

Roiser J.P., Sahakian B.J. (2013) Hot and cold cognition in depression. CNS Spectr., 18(3): 139-149.

\section{Принципы терапии когнитивных нарушений при депрессивных расстройствах}

\section{С.А. Ярославцев}

Резюме. Цель - разработать и оценить эффективность комплексной программы терапии и реабилитации (КПТР) пациентов с когнитивными нарушениями (КН) при депрессивных расстройствах (ДР). Предложенная КПТР пациентов с КН при ДР реализовывалась в четыре этапа: диагностический, терапевтический, реабилитационный и профилактический. Диагностический этап включал клинико- 
психопатологическую оценку имеющихся расстройств когнитивной сферы, анализ анамнестических данных, клинической симптоматики, динамики и прогноза заболевания, взаимосвязи клинических и социально-психологических факторов. Терапевтический этап включал комплекс мероприятий фармакотерапии и психотерапии, направленных на коррекцию КН, купирование депрессивной симптоматики, нормализациюпсихоэмоционального состояния, социальной адаптации и реадаптацию пациента. Реабилитационный этап включал комплекс мероприятий фармакотерапии и психотерапии, направленных на восстановление когнитивных функций, укрепление эффекта антидепрессивной терапии, восстановление социального функционирования пациента. Профилактический этап предназначен для поддержания нормального психоэмоционального состояния, эффективного сопротивления стрессу, предотвращению рецидивов ДР. В апробации разработанной КПТР участвовали 97 пациентов с КН при ДР, составивших основную группуи прошедших курс КПТР по разработанной программе. Контрольная группа состояла из 93 больных с КН при ДР, прошедших курс терапии по традиционной схеме. Доказана эффективность предложенной КПТР пациентов с КН при ДР, заключающаяся в более выраженной редукции клинических проявлений ДР, улучшении когнитивных функций, снижении неадаптивных и повышении адаптивных стратегий когнитивного регулирования эмоций, улучшении социального функционирования в основных сферах жизнедеятельности.

Ключевые слова: когнитивные нарушения, депрессивные расстройства, терапия, реабилитация, социальное функционирование

\section{Principles of therapy of cognitive impairment in depressive disorders \\ S.0. Yaroslavtsev}

Summary. The aim was to develop and evaluate the effectiveness of a comprehensive program of therapy and rehabilitation (CPTR) for patients with cognitive impairment (CI) in depressive disorders (DD). The proposed CPTR for patients with $\mathrm{Cl}$ in $\mathrm{DD}$ implemented in four stages: diagnostic, therapeutic, rehabilitation and prophylactic. The diagnostic stage included a clinical and psychopathological assessment of the patients' $\mathrm{Cl}$, an analysis of anamnestic data, clinical symptoms, dynamics and prognosis of the disease, the relationship of clinical and socio-psychological factors. The therapeutic stage included a set of pharmacotherapy and psychotherapy measures aimed at correcting $\mathrm{Cl}$, stopping $D D$, normalizing the psycho-emotional state, social adaptation and readaptation of the patient. The rehabilitation stage included a set of pharmacotherapy and psychotherapy measures aimed at restoring cognitive functions, strengthening the effect of antidepressant therapy, and restoring the patient's social functioning. The preventive stage designed to maintain a normal psycho-emotional state, effectively resist stress, and prevent the recurrence of depressive disorders. In approbation of the developed CPTR, 97 patients with $\mathrm{Cl}$ in DD make up the main group, who passed the CPTR course according to the developed program. The control group consisted of 93 patients with $\mathrm{Cl}$ in $\mathrm{DD}$ who underwent a course of therapy according to traditional schemes. The effectiveness of the proposed CPTR in patients with $C I$ in $D D$ were proved, which consists in a more pronounced reduction of clinical manifestations of $D D$, improvement of cognitive functions, reduction of maladaptive and increase in adaptive strategies for cognitive regulation of emotions, improvement of social functioning in the main spheres of life.

Key words: cognitive impairment, depressive disorders, therapy, rehabilitation, social functioning.

\section{Адреса для листування:}

Ярославцев Сергій Олександрович

Херсонська обл., с. Степанівка, вул. Джона Говарда, 65

КНП «Херсонський обласний заклад 3 надання психіатричної допомоги»

E-mail: kalenskaya_galina@ukr.net

Одержано 29.10.2020 